Journal of Education and Vocational Research

Vol. 4, No. 9, pp. 275-286, Sep 2013 (ISSN 2221-2590)

\title{
Budgeting and Fund Allocation in Higher Education in Ghana
}

\author{
Emmanuel Newman \\ National Council for Tertiary Education, Ghana \\ emmanuelnewman@yahoo.com
}

\begin{abstract}
The National Council for Tertiary Education (NCTE) the coordinating body for tertiary education in Ghana) and the Ministry of Education established norms in the early 1990s to assist higher education institutions in planning and ensuring efficiency of their operations and foster performance monitoring and evaluation. The norms also serve as standardised input factors for budgeting and allocation of public funds for higher education. During the past years, budgetary allocation to higher education institutions for recurrent expenditure has fallen short of the norm-based costs. Indeed, the difference between the normbased costs of university education and resources made available to the institutions by the Government were $28.9 \%$ in $2005 / 06$ and $23.4 \%$ in $2009 / 10$. The consequence of the inability of the state to provide funds to meet the norm-based costs of higher education is the breakdown of norm-based budgeting which was instituted in the early 1990s and a reversion to incremental and ad-hoc budgeting without due regard to the volume of activities performed by the institutions. This development has had grave consequences for equity and efficiency in fund management in higher education. This work assesses the factors behind the discontinuance of the norm-based budgeting approach and the use of the incremental budgeting approaches in higher education in Ghana.
\end{abstract}

Keywords: Higher Education, Budgeting and Fund Allocation, Revenue Theory of Costs, Funding Mechanisms

\section{Introduction}

The role of the state in financing higher education in Ghana, as in many other African countries during the postcolonial period, has been justified by the need to train a corps of professionals to replace the departing expatriate civil servants and managers. It is also argued that the participation of the state in higher education was necessary to promote access of needy students who have demonstrated capacities for advanced learning. Competition for limited public resources by the various sectors of the economy; and between higher education institutions and other sub-sectors of education, has led to calls for higher education institutions to make more efficient use of public resources and be more accountable. Indeed, when resources are in short supply, there is the need to apply the available resources in an efficient and transparent manner for the maximum benefit of society. There is also the need for the institutions to be more relevant and accountable in view of the huge public expenditure incurred to sustain their operations. Moreover, they should contribute to the production and dissemination of new knowledge and be responsive to the socio-economic challenges facing society. It is also imperative that the mechanism for appropriating and distributing public grants to higher education institutions re-enforce these objectives.

During the early 1990s, the process of budgeting and funding allocation in higher education in Ghana was based on incremental and negotiated budgeting mechanisms. Indeed, the budgeting and fund allocation was based on annual requests for public funds by higher education institutions and negotiations undertaken on behalf of the institutions by the then National Council for Higher Education with Ministry of Finance. The University Rationalisation Committee (A Committee established to make recommendations for reforms in higher education in 1988) noted that attention was focused on extra resources to cover expenses on staff and administrative activities. Funding was not based on the volume of activities undertaken by the institutions or national objectives for higher education. Indeed, there was no well-defined mechanism for budgeting and funding allocation in higher education. In this regard, the Government of Ghana decided that funding of higher education would be programme-linked; and norms would be developed to delineate costs based on the student as the unit of production to foster efficiency. However, assessment of the present fund allocation mechanism in tertiary education shows that the norm-based mechanism for budgeting and fund allocation in 
Ghana has been abandoned. This is because the norm-based funding of higher education has not been effective instrument for public policy implementation in higher education.

The basis of the norm-based budget model is not planned goals of higher education and increasing costs without equivalent funding from government has rendered the model inoperable. The consequence of the inability of the state to provide funds to meet the norm-based costs of higher education is the breakdown of norm-based budgeting which was instituted in the early 1990s and a reversion to incremental and adhoc budgeting without due regard to higher education policy and national development imperatives. This development has had grave consequences for equity, accountability and efficiency in higher education. Presently, the NCTE does not set budgetary ceilings for higher education institutions, rather, the institutions present budgets based on various line-items, which are repeated year after year irrespective of the changes in the volume of activities performed by the institutions. Funds allocated to the sub-sector by the state, depends on negotiations undertaken on behalf of the institutions by the NCTE. Distribution of funds depends on the quantum of funds requested by the institutions. Thus, the funding arrangements neither incorporate performance indicators nor pre-determined outcomes. From these developments, it could be surmised that:

- The present arrangement for budgeting and distribution of public funds in higher education does not provide incentives for public policy implementation;

- Higher education funding is not linked to specified outputs and outcomes;

- The line-item and incremental budgeting approach to budgeting and distribution of public funds does not provide incentives for reform and innovation (Girdwood, 1999).

In view of the foregoing, the purpose of this work is to assess the reasons for the failure of the norm-based budgeting system in tertiary education in Ghana and make recommendations for reforming the budgeting and fund allocation mechanisms in tertiary education to foster the realisation of sector goals. This paper is therefore guided by the following questions:

- What factors prompted changes in the mechanisms for budgeting in tertiary education in the early 1990s in Ghana?

- What are the causes of the failure of the norm-based approach to funding higher education in Ghana?

- How can funding be linked to national development goals in tertiary education?

\section{Conceptual and Theoretical Perspectives}

Revenue Theory of Costs in Higher Education: The revenue theory of cost as propounded by Bowen (1980:18) posits that the unit cost of higher education institutions is determined neither by rigid technological requirements for delivering educational services nor by abstract standard of need, but by the revenue available for education that can be raised per student unit. According to Bowen (1980:18), the control of costs is diffused since the institutions endeavour to maximise revenues from various sources public, private and income generating activities. Moreover, the institutions spend as much as they raise to promote their honour, prestige and excellence and these expenditures have the effect of increasing costs. Bowen (1980:20) states that public higher education institutions as non-for-profit organisations have neither strong incentive to cut cost, nor forced by competition to lower cost to survive. This is due to the fact that they are subsidised by philanthropy and partly because they are shielded from competition by geographic location and differentiation of services. Further, (Bowen, 1980) states that due to inadequate knowledge about relationship between expenditures and outcomes; there is the tendency to drift into the belief that increasing expenditures will automatically boost outcomes. It is stated that within wide limits, institutions can adjust to available funds such that when resources are increased, expenditure increases and unit costs go up; and when resources are decreased expenditures decreases and unit costs accordingly decreases (Bowen, 1980).

It is therefore stressed that public funding of higher education cannot be open-ended. Thus, the duty of establishing ceilings regarding educational costs rests on those who provide the money - funding agencies. In 
this regard decisions regarding funding of public institutions are to be reached through the political process, informed by the principle of equi-marginal returns to all areas such that marginal returns to higher education are balanced against marginal returns to other uses of public funds (Bowen, 1980). Additionally, Bowen (1980) notes that when public agencies want to control costs, they should establish in broad terms the basic scope and mission of the institutions for which they are responsible and set the total amount of money available to each institution. Individual institutions should then employ their own internal mechanisms to allocate the funds internally to protect their autonomy. Fincher (1981) states that institutions differ in the minimum and maximum amounts they spend on instruction. Furthermore, Fincher (1981) based on experiences in the United States, notes that educational costs are not definite, and that, educational expenditures per student differ for different institutions. Fincher (1981) therefore makes the following observations regarding the dynamics behind costs in higher education:

- Institutions are not comparable regarding expenditure;

- Differences in institutional cost should be understood in the contexts of decisions and commitments in public policy, regional and state differences as well as stages of development of higher education institutions;

- Educational costs are a function of time and circumstance in which start-up funds are made available; and

- Educational costs are a function of administrative skills in negotiating budgets and the bargaining skills of individual faculty members.

Fincher's analysis of the dynamics behind educational cost in higher education affirms Bowen's assertion that unit cost of higher education institutions is determined not by rigid technological requirements for delivering educational services. The present research associates with Bowen's suggestion regarding the funding of public higher institutions to the effect that decisions concerning funding of public higher education are within the purview of the political process. Thus, in providing funds for higher education institutions, funding agencies should define the scope and mission of higher education and set the available funds to it.

Budgeting and Fund Allocation in Higher Education: Budgeting and funding models in higher education relates to the procedures used by governmental authorities in appropriating and/or allocating public funds to higher education institutions. Various budgeting and funding models are used by different countries to allocate public funds to higher education institutions. The choice of a budgeting mechanism depends on the objectives sought by the funding authority; and the degree of control which government authorities wish to exercise over higher education institutions. Sanyal (1995) observes that the state requires a mechanism that can steer, control the higher educational system, and provide a means for ensuring value for money and protection against bad management. This quest for value for money has led to the evolution of various budgeting models in higher education. In this work we assess incremental budgeting and formula-based budgeting in higher education.

Incremental Budgeting: In this form of budgeting, a flat increment is applied on a historical base; normally, the previous year's budget (Ziderman and Albrecht, 1992, Layzell, 1999, Sanyal, 1995). The increment may be a subject of negotiations between the funding authorities and higher education institutions. Funding could be in the form of a block grant or in accordance with budgetary request submitted in line-items by the institutions. The determination of levels of funding for individual institutions could be based on outcomes of negotiations between the institutions and government. Such negotiations with the government could be undertaken by the institutions themselves or by a buffer organisation. The outcome of such negotiations is announced as part of public appropriations for the fiscal year. In incremental funding, the allocation of public funds may neither be related to the changes in the levels of activities undertaken by the institutions; nor specific institutional characteristics. The process may perpetuate inefficiencies in the higher education system and gloss over historical inefficiencies in the funding of individual institutions. Moreover, it presents no incentives to the institutions to respond to changing trends in their environment. As stated earlier, the increments could be applied on line-items (staff emoluments, administration, investments) which form part of the budget of the ministry responsible for education and approved legislature as part of annual fiscal appropriations. Line-item budgeting places restrictions on university administrators, regarding choices in the administration of funds (Salmi and Hauptman, 2006). Moreover, in line-item budgeting, it is difficult to 
respond to issues that emerge after funding levels have been approved. Thus, line-item budgeting enhances state control and do not foster long-term financial planning in higher education institutions (van der Laan, 2000).

Formula-based Budgeting: Formula-based budgeting evolved as a result of the quest for identifying adequate and predictable resource base for higher education and a means to allocate public resources equitably to higher education institutions (Mckeown, 1996). According to Miller (1964), formula-financing presents an objective procedure for estimating the future budgetary requirements of a college or university through the manipulation of objective data about future programmes, and relationships between programmes and costs, in such a way as to derive an estimate of future costs. Funding formulas provide a means to simplify and systematise the political processes involved in decisions regarding the allocation of public resources to tertiary education institutions (Mckeown, 1996, Layzell and Mckeown, 1992). They (funding formulas) ensure equity regarding fund allocation in tertiary education and provide justification for higher education budgets to members of national legislatures. Funding formulas may also be developed for the following purposes:

To clarify budgetary information to members of state legislatures and the public; to standardise budgetary data for comparative analysis; to distribute public resources among and within institutions; and to project and systematise institutional budgetary needs (Halstead ,1974). Mackeown (1996) states formula-financing is deemed to reduce political competition and lobbying by the institutions; present a reasonable compromise between public accountability and institutional autonomy; and permit policy makers to focus on basic policy questions. Funding-formulas have been criticised for having several disadvantages. For instance, it is said that funding formulas reduce all academic programmes to a common level of mediocrity by funding each programme the same. This is because quantitative measures cannot assess the quality of a programme and that enrolment driven formulas may be inadequate to meet the needs of the changing clientele bases or new programme initiatives (MGT of America, 2001). Another shortcoming of funding formulas is that student numbers are mostly as used base factors for the estimation of funding requirements of institutions and this presents difficulties regarding stability of financial resources for institutions in the period of major fluctuations in enrolments.

\section{Methodology}

In this paper a qualitative and quantitative analysis of the mechanisms for allocation of public funds to tertiary education institutions in Ghana is presented. The analysis focused on data, policies, legislations and reports obtained from the Ministry of Education and the National Council for Tertiary Education (the main regulatory body for tertiary education in Ghana).

Data Collection: Primary data was collected from officers responsible for policy and fund allocation in the afore-named ministry and agency as well as persons who are knowledgeable regarding the mechanisms for allocating funds to tertiary education institutions. These officers (Planning Officers and budget officers) were purposely selected to provide information on policy, budgeting and fund allocation in tertiary education in Ghana.

\section{Results and Analysis}

Higher Education Reforms in Ghana: The vision for reforms in higher education in Ghana was formulated by the University Rationalisation Committee (a committee established by the Government of Ghana), which presented its report to the then Ministry of Education and Culture in 1988. Thereafter, the Government published the White Paper on the Reforms to the Tertiary Education System in Ghana in 1990, to provide the basis for wide-ranging reforms to the higher education sub-sector. The goals of the reforms were to establish an integrated and co-ordinated higher education system comprising all post secondary pre-service training institutions under the general supervision, direction and control of the Ministry of Education (Government of Ghana, 1990). This is to ensure that higher education is co-ordinated with all other sub-sectors of the education system taking into cognisance the overall national development and educational policies and priorities. Other goals of the reforms outlined in the Government White Paper were to: 
- Make higher education more cost-effective; and provide quality education for increasing numbers of students through increased efficiency in the utilisation of space, resources and personnel;

- Provide for greater access to higher education for qualified people and significantly increase the proportion of women students; and

- Restructure enrolment and output of tertiary institutions to achieve an appropriate balance in the provision of skills in science, technology, social sciences, humanities and the arts in relation to national needs.

Others goals were related to the supply of higher level and technician level personnel; and the introduction of programmes essential to the training needs of working people for national development. In order to put the goals into operation, medium-term targets to be attained by all tertiary education institutions to facilitate efficiency in the utilisation of resources were developed.

Higher Education Funding Mechanism in Ghana: The Status Quo-Ante: Before the reforms to the higher education system in the early1990s, funding of universities was effected through the public budgetary system. Thus, at the beginning of the fiscal year, the then Higher Education Secretariat published fiscal procedures of Government and requested public universities to submit their budgetary estimates outlining recurrent and capital expenditure for the ensuing year (Government of Ghana , 1988). Consequently, the universities normally increased their previous year's expenditure; and together with other background data on their finances; submitted their budgetary estimates to the Higher Education Secretariat. The estimates were assessed by the Higher Education Division of the Ministry of Education, which in turn submitted and defended the budget of the sub-sector at the Ministry of Finance and Economic Planning (Government of Ghana, 1988). The budgetary allocations to the sub-sector were agreed upon in the light of the available budgetary resources and submitted to the government for approval. Usually there were differences between the budget and the actual level of funds allocated as shown in the percentages of the budget and funds allocated by the government to the then three public universities. For instance, the budget agreed and funds allocated to public universities in Ghana, as noted by the Government of Ghana in 1988, were as follows:

\begin{tabular}{lcc}
\hline Universities & Agreed Budget & Actual Allocation \\
\hline University of Ghana & $77 \%$ & $51 \%$ \\
University of Science and Technology & $53 \%$ & $30 \%$ \\
University of Cape Coast & $45 \%$ & $30 \%$ \\
\hline
\end{tabular}

The process of budgeting and allocation of public funds presented several difficulties. These difficulties have been summarised by Girdwood (1999) and Government of Ghana (1988):

- There were no well defined standards for budgeting and disbursement of public funds for higher education;

- According to the Government of Ghana (1988), the emphasis of budgeting and distributing of public funds was on the object of expenditure, and so focussed on activities in terms of their input costs largely unrelated to outputs or outcomes;

- The line-by-line incremental budgeting to justify the acquisition of public funds for higher education did not provide incentives for reforms and innovation;

- This method of preparing university estimates is deficient from the point of view of overall planning and control (Government of Ghana 1988); and unrelated to the volume of activities undertaken by the institutions; and

- The budget process could not be used as an instrument for public policy implementation.

The Government of Ghana (1988) again notes that there was no model to justify the staffing structure of public universities; and attention was largely focused on demands for extra resources to cover staff emoluments and administrative expenses. Additionally, funding was neither focused on the volume of activities performed by the institutions nor the objectives of academic programmes organised by the 
universities. These concerns prompted the development of a norm-based funding mechanism to calculate the unit cost per student as the basis for determining the funding requirements for higher education institutions.

Higher Education Norms: As part of the reforms in the early 1990s, norms (known as Nationally Approved Norms) were developed to foster performance management in higher education in Ghana. These norms are quantified objectives for the higher education sector delineated to facilitate efficiency in the operations of higher education institutions and the determination of funding requirements for higher education.

Table 1: Nationally Approved Norms

\begin{tabular}{lcc}
\hline Description & Universities & Polytechnics \\
\hline Student /Teacher Ratios & Norms & Norms \\
Humanities/Business & $18: 1$ & $20: 1$ \\
Science/Technology & $12: 1$ & $15: 1$ \\
Medicine & $8: 1$ & $\mathrm{~N} / \mathrm{A}$ \\
Engineering & $12: 1$ & $12: 1$ \\
Pharmacy & $12: 1$ & $\mathrm{~N} / \mathrm{A}$ \\
Education & $20: 1$ & $\mathrm{~N} / \mathrm{A}$ \\
& & \\
Staff Mix at Departments & & \\
Professors/Principal Lecturers & $20 \%$ & $20 \%$ \\
Senior Lecturers & $30 \%$ & $50 \%$ \\
Lecturers/Tutors & $50 \%$ & $30 \%$ \\
& & \\
Enrolments & & \\
Annual Growth in Enrolments & $10 \%$ & $15 \%$ \\
Male/Female Participation Ratio & $50: 50$ & $50: 50$ \\
Science/Social Science Enrolment Ratio & $40: 60$ & $60: 40$ \\
Post Graduate Enrolment & $10 \%$ & - \\
\hline
\end{tabular}

Source: National Council for Tertiary Education

The Nationally Approved Norms were also meant to provide a framework for performance monitoring in higher education to ensure that standards were implemented for achievement of efficiency (National Council for Tertiary Education, 1998). The norms were also meant to provide efficient and objective framework for financing higher education. The nationally approved norms included standardised student/teacher ratios; the academic staff mix; and the rate of growth of student enrolments. For instance, the student/teacher ratio of Humanities/Business programmes for the universities and polytechnics were 18:1 and 20:1 respectively; while the student/teacher ratios for Science/Technology programmes were 12:1 and 15:1 for polytechnics and universities. Moreover, the standard for the structure of academic staff were 20:30:50 respectively for professors, senior lecturers and lecturers. The full schedule of the nationally approved standards and norms are in Table 1. The annual growth in enrolments was pegged at $10 \%$ and $15 \%$ respectively for universities and polytechnics. As shown above, it was planned that the ratio of males and females enrolled in higher education institutions in Ghana should be the same; moreover, planned enrolment ratio of science students to social science/humanities students is 60:40.

The Budget Model for Financing Public Higher Education Institutions: Problems associated with the mode of financing higher education institutions led to the institution of a new funding framework focused on the student as the unit of production. In fact, the Government of Ghana (1988) established that: "The student should become the focus of the costs and redistribution of funds". It was determined that the new budgeting system should be programme-linked and focused on the student as the unit of production. Thus, costing and budgeting in higher education would accord with the cost per student or unit cost approach to funding higher education. Programme-linked budgeting breaks down university activities into programmes with each programme generating well-defined results and budget presentation showing the estimated costs of each programme and their breakdown (Sanyal, 1995). Generally, cost per student defines the resources required for training one student. The cost relates to instructional or educational cost. 
The number of students is not computed by head count, but by the Full Time Equivalent Units. This computation would remove difficulties that would arise by counting part-time and full-time students and computing with accuracy the exact number of students belonging to the departments of an institution since students register for courses in various departments. The full- time equivalent units are computed by counting full-time students as one each and counting part-time students as fraction of one according to the number of credit hours for which they are enrolled (Bowen, 1980). The development of the norm-based budget model which is partly adopted from Andy Brock (1996) is as follows:

- A notional departmental cost is calculated by assuming 10 academic staff of different ranks (2 professors, 3 senior lecturers, and 5 lecturers). The normative requirement of academic staff per academic department is multiplied by the prescribed salaries and allowances to give the total emoluments for an academic department.

- The cost of the support staff (administrative and technical staff) is calculated according to the schedule in Table 2 and added to the cost of academic staff.

Table 2: The Cost of Non-Academic Staff and Administrative Support Staff

\begin{tabular}{ll} 
Senior Administrative Staff & $=33.3 \%$ of total cost of academic staff \\
Senior Technical & $=16.7 \%$ of total cost of academic staff \\
Junior Technical Staff & $=100 \%$ of total cost of academic staff \\
Junior Non-Technical Staff & $=100 \%$ of total cost of academic staff \\
\hline
\end{tabular}

Source: National Council for Tertiary Education

The cost of goods and services are calculated as per rates provided in Table 3 (norms on goods and services) and added to the cost of academic and non-teaching staff. These rates are calculated as per percentages of staff cost as stated in Table 3.

Table 3: Norms on Goods and Services

\begin{tabular}{|c|c|c|}
\hline Goods and Services & Universities (\%) & Polytechnics (\%) \\
\hline Humanities/Business & 20 & 20 \\
\hline Science & 35 & $\mathrm{~N} / \mathrm{A}$ \\
\hline Engineering & 50 & 50 \\
\hline Applied Science and Technology & 40 & 50 \\
\hline
\end{tabular}

Source: National Council for Tertiary Education Ghana

Thus, for university humanities and business programmes $20 \%$ of total staff cost is calculated as the cost of goods and services and added to the cost of academic staff to realise the departmental cost.

The cost per teaching unit is calculated by dividing the departmental cost total by ten. And, the cost per student is calculated by dividing the unit teaching cost by the approved staff/student ratio for the programme concerned. The approved staff/student ratios for the various programmes in universities and polytechnics are provided in Table 4. Therefore, in estimating the cost per student for the department of medicine, the unit teaching cost of the department will be divided by 8 .

Table 4: Nationally Approved Norms on Student/Teacher Ratios

\begin{tabular}{lll}
\hline Description & Universities & Polytechnics \\
\hline Programmes & Student /Teacher Ratios & Student /Teacher Ratios \\
Humanities/Business & $18: 1$ & $20: 1$ \\
Science/Technology & $12: 1$ & $15: 1$ \\
Medicine & $8: 1$ & $\mathrm{~N} / \mathrm{A}$ \\
Engineering & $12: 1$ & $12: 1$ \\
Pharmacy & $12: 1$ & $\mathrm{~N} / \mathrm{A}$ \\
Education & $20: 1$ & $\mathrm{~N} / \mathrm{A}$ \\
\hline
\end{tabular}

Source: National Council for Tertiary Education 
- The departmental budgets are calculated by multiplying the full-time equivalent student total for that department by the unit cost per student. The sum of all the departmental budgets will give the direct teaching cost, which represent $45 \%$ of the total university budget.

- The remaining 55\% cover expenses for central administration, library and general educational expenditure and municipal services, etc. The details of the cost components are in Table 5.

Table 5: Distribution of Non-Teaching Cost

\begin{tabular}{lll}
\hline Cost Component & Percentage \\
\cline { 1 - 1 } General Educational Expenditure & & $15 \%$ \\
Central Administration Expenditure & $6 \%$ \\
Library Cost & $10 \%$ \\
Municipal Services & $15 \%$ \\
Student and Staff Facilities & $5 \%$ \\
Miscellaneous Expenses & $4 \%$ \\
\hline
\end{tabular}

Source: National Council for Tertiary Education

The general educational expenditure (expenditure on study leave, sabbaticals, cost of examinations, expenditure related to academic ceremonies , activities of the Academic Board and its committees, allowances of external examiners, university official publications, university-wide computer facilities, data processing and programming, travel costs and relationship with other institutions and cost of linkage arrangements) is $15 \%$.While, the norms for library cost, as well as, the cost of municipal facilities are $10 \%$ and $15 \%$ respectively.

Table 6: Norm-Based Cost per-Student per Discipline-Universities (2005/06 to 2009/10)

\begin{tabular}{|c|c|c|c|c|c|}
\hline Discipline & $\begin{array}{l}2005 / 06 \\
\text { Ghథ }\end{array}$ & $\begin{array}{l}\text { 2006/07 } \\
\text { Ghథ }\end{array}$ & $\begin{array}{l}2007 / 08 \\
\text { Ghథ }\end{array}$ & $\begin{array}{l}\text { 2008/09 } \\
\text { Ghథ }\end{array}$ & $\begin{array}{l}2009 / 010 \\
\text { Ghd }\end{array}$ \\
\hline Science & $5,345.58$ & $5,516.97$ & $6,071.00$ & $6,991.00$ & $7,769.00$ \\
\hline Humanities & 2962.55 & $3,054.51$ & $3,409.00$ & $3,922.00$ & $4,360.00$ \\
\hline Applied Science & $5,543.57$ & 5721.30 & $6,296.00$ & $7,249.00$ & $8,056.00$ \\
\hline Engineering & $5,939.54$ & $6,129.97$ & 6744.00 & $7,767.00$ & $8,631.00$ \\
\hline Medicine & $8,813.28$ & $9,079.89$ & $9,878.00$ & $11,309.00$ & $12,520.00$ \\
\hline Pharmacy & $6,652.28$ & $6,865.56$ & $7,553.00$ & $8,700.00$ & $9,667.00$ \\
\hline Weighted Average Cost Per Student & $3,273.56$ & $4,847.22$ & $6,184.00$ & $7,113.22$ & $7,899.75$ \\
\hline Public Grant Per Student & 949.307 & 1086.47 & 961.16 & 1169.88 & 1854.98 \\
\hline Total Recurrent Revenue Per Student & 1,366 & 1,648 & 1,576 & 1,986 & 2,916 \\
\hline
\end{tabular}

Source: National Council for Tertiary Education

Using the model narrated above, the norm-based unit costs of the various academic disciplines in public universities from the 2005/06 to the 2009/10 academic year are as presented in the Table 6 . Thus, for 2009/2010 academic year, the weighted average cost per student (norm-based) in public universities was Gh\$ 7,899.75, whilst the cost per student for engineering and humanities programmes were Gh\$ 8,056 and Gh\$ 4,360 respectively. These figures do not include the cost of research .The cost of research is $15 \%$ of direct teaching cost and non-teaching cost.

Assessment of the Norm-Based Budget Model: The description of the budget model is clearly not a programme-linked budget as demanded by the Government of Ghana, since the budget development is not linked to specified programme goals. According to Brock (1996:120), the model could be best described as norm-based budgeting or input-based budgeting. It does not take as its starting point the planned goals of higher education or the development priorities of government. Moreover, the basis of the model is the notional costs of a department and not the real cost. And the focus of the model is on the price of inputs, and not the most efficient combination of inputs to achieve a desired output (Brock, 1996:120). The model has the effect of promoting enrolment in higher education; and indeed, rapid enrolment (above the planned targets) 
and increasing staff emolument have rendered the funding system inoperable. Indeed, from 2005/2006 to $2009 / 10$ enrolments in universities and polytechnics increased by a factor of 1.23. Data available from NCTE indicates that staff emoluments for the sector increased by more than $100 \%$ within the same period.

Table 7: Norm-Based Funding Requirements and Requirement Funding-Universities (2005/06 to 2009/10)

\begin{tabular}{|c|c|c|c|c|c|c|}
\hline Funding Categori & & $2005 / 06$ & $2006 / 07$ & $2007 / 08$ & $2008 / 09$ & $2009 / 010$ \\
\hline $\begin{array}{l}\text { Public Recurrent } \\
\text { (Ghథ) }\end{array}$ & Funding & $83,961,489.00$ & $102,098,887.00$ & $98,565,718.00$ & $125,245,599.00$ & $213,965,437.00$ \\
\hline $\begin{array}{l}\text { Total Recurrent } \\
\text { (Ghథ) }\end{array}$ & Funding & $120,846,676.00$ & $154,853,240.00$ & $161,601,193.00$ & $212,663,698.00$ & $336,357,401.00$ \\
\hline $\begin{array}{l}\text { Norm-Based } \\
\text { Requirements (Gh }\end{array}$ & Funding & $289,530,014.20$ & $455,507,805.06$ & $634,156,832.00$ & $768,128,174.92$ & $911,204,563.50$ \\
\hline
\end{tabular}

From 2005/06 to 2010 public grants and total recurrent grant (public grant and internally generated funds) for higher education had not matched the funding requirement estimated with the norm-based funding model. For instance, during the period under review, public grants and total recurrent funding for higher education has fallen short of norm-based funding requirements. Indeed, public recurrent funding and total recurrent funding for public universities during the 2005/06 fiscal year were about $30 \%$ and $41 \%$ of total funding requirements respectively. And as shown in Table 7, the public recurrent funding and total recurrent funding for higher education in $2009 / 2010$ was about $23 \%$ and $36.9 \%$ of the norm-based requirements respectively. The consequence of the inability of the state to provide funds to meet the norm-based costs of higher education is the breakdown of norm-based funding and reversion to incremental budgeting.

The Present Sector Budgeting and Fund Allocation in Higher Education: At present, the National Council for Tertiary Education does not set budgetary ceiling for higher education institutions. At the beginning of every fiscal year, the institutions present budgets based on various line-items categorised under personal emoluments, administration, service activities and investments. Funds allocated to the sub-sector depend on negotiations undertaken on behalf of the institutions by the NCTE with the Ministry of Education and the Ministry of Finance and Economic Planning. Distribution of funds depends on the quantum of funds requested by individual institutions and negotiations undertaken by the National Council for Tertiary Education. Finally, levels of funding agreed between the NCTE and the Ministry of Finance and Economic Planning becomes part of public appropriation, which must be approved by the legislature. As indicated earlier, the budget of higher education has increased annually irrespective of the volume of activities conducted by the institutions. Though staff emoluments have increased tremendously annually during the years under consideration, there is no criterion for justifying the required faculty for higher education institutions.

Brock (1996) noted that Ghanaian universities could be placed in the academic oligarchy (collegial) model coordination. That is, in spite of the statutory role of the NCTE, senior academics are in charge of the levers of power in higher education in Ghana. It should be noted that this model (collegial or academic oligarchy) is distinguished by the fact that the institutions are heavily dependent on state funding but with little accountability. Adu and Opoku-Afriyie (2002) note that performance monitoring of higher education in Ghana is poor and this is attributable to the fact that the NCTE does not have any effective mechanisms to ensure compliance with its norms, which are mostly ignored by the institutions. Moreover, due to inadequate funding, there is general lack of interest in the norms by the institutions. The present funding arrangement for higher education in Ghana is untenable. In fact, it neither re-enforces the implementation of public policy objectives for higher education nor ensures equitable distribution of public funds to higher education institutions. Additionally, there are no in-built indicators for performance monitoring and general lack of direction. From these developments, it could be concluded that: The standards for appropriation of public funds for tertiary education in Ghana has been abandoned; as a result the National Council for Tertiary Education employs no well-established criteria for the distribution of public funds to individual public higher education institutions.

Higher education funding is not linked to specified goals and outcomes; additionally, the line-item budgeting and incremental approach used to justify the appropriation and disbursement of public funds does not provide incentives for reform and innovation. Indeed, the present funding arrangement for tertiary education 
appears to be arbitrary and does not reinforce policy imperatives for tertiary education. According to Adu and Opoku-Afriyie, 2002, the management of higher education institutions does not employ standard performance indicators in the management of resources. Thus, the application of public funds in state-owned universities is not geared towards pre-determined outcomes and this invariably leads to wastage and inefficiency. There also challenges regarding the application of common norms for all tertiary education institutions. The delineation of common norms for all higher education institutions in Ghana, each having different antecedents that led to their creation, different enabling Acts and unique missions and located in different geographic areas is very problematic. Indeed, Binsbergen (1996) et al stated that, "Higher education institutions can be characterised by their organisational multiplicity and variety, with agencies and programmes piling up in ways that are sometimes supplementary but more often duplicative or overlapping and occasionally conflicting. But these multiplicities and redundancies should not automatically lead to the wish to redefine the organisation, to simplify its governance structure".

There was no level playing field in the implementation of the norms and standards delineated for tertiary education institutions. Each institution had different resources and capacities; and due to the antecedents that led to their creation had laid emphasis in different academic areas. Thus, it would be improper to require all the institutions to reach the same performance goals. For instance, the Kwame Nkrumah University of Science and Technology emphasises engineering while the University of Ghana lays emphasis on the humanities and social sciences. According to Girdwood (1999), the use of the norms such as staff: student ratios for the computing institutional funding may lead to the preservation of historical disciplinary structure which ceases to be desirable as external conditions change, or as the institutions staffing composition changes. Additionally, Girdwood (1999) notes that without a mechanism for regularly reviewing the norms, their institutional relevance would not be maximised. The above analysis presents a challenge for developing a mechanism for allocating public grants to higher education institutions to focus on the student as the unit of production; and address concerns such as efficiency, equity and transparency. Additionally, the new funding mechanism should reinforce the policy priorities for higher education.

\section{Conclusion and Recommendations}

In this work, the reasons for the failure of the norm-based budgeting system in tertiary education in Ghana was assessed to facilitate the provision of recommendations that could lead to reforms in the funding of the public tertiary education system in Ghana. Indeed, the reasons for the failure of the norm-based funding approach to funding tertiary education in Ghana are not far-fetched. First, the focus of the model is the price of inputs and not the most efficient combination of inputs to achieve the desired output (Brock, 1996). The basis of the model is the notional costs of a department and not the real cost. Indeed, the model has the effect of promoting enrolment in higher education; and indeed, rapid enrolment (above the planned targets) and increasing staff emolument have rendered the funding system inoperable. From 2005/2006 to 2009/10 budgetary allocation to higher education institutions for recurrent expenditure fell short of norm-based costs. Second, the bases for funding tertiary education were not planned outputs of tertiary education. The fund allocation model was not programme-linked as initially thought. In fact, the starting point of the fund allocation model was not planned goals of tertiary education; and the net effect of the foregoing is that the norm-based funding model could not be used as an instrument of public policy.

Bowen (1980) states that the unit costs of higher education institutions are mainly due to the amount of money institutions are able to raise per unit of service rendered than by the inherent technological requirement of conducting their work. Bowen (1980) states that within wide limits, institutions can adjust to available funds such that when resources are increased, expenditure increases and unit costs go up; and when resources are decreased expenditures decreases and unit costs accordingly decreases. Further Bowen (1980) notes that when public agencies want to control costs, they should establish in broad terms the basic scope and mission of the institutions for which they are responsible and set the total amount of money available to each institution. Individual institutions should then employ their own internal mechanisms to allocate the funds internally to protect their autonomy. These positions are affirmed by the National Centre for Public Policy in Higher Education (2003) of the USA which stated that a state needs the political will to set public agenda, to formulate clear definitions of the public purposes it expects its higher education institutions to attain. As the needs of society evolve, the ends a state seeks to achieve through its colleges and universities 
can also change. Bowen (1980) again notes that decisions regarding funding of public institutions are to be reached through the political process, informed by the principle of equi-marginal returns to all areas in the funding of public higher education institutions such that marginal returns to higher education are balanced against marginal returns to other uses of public funds.

Based on the proposition of Bowen (1980) it is proposed that the Government of Ghana acting in concert with the National Council for Tertiary Education and tertiary institutions should regularly assess the developments in the tertiary education system and determine mission and purposes of tertiary education in Ghana as the basis for allocating public funds tertiary education institutions. The afore-made recommendations impose responsibilities on the Ministry of Education, the National Council for Tertiary Education and tertiary education institutions. The Ministry of Education, as in other countries, has general oversight for the development of education in Ghana. Consequently, the Ministry has responsibility for setting the policy agenda and instituting a mechanism for regular review of the higher education policy. The Ministry of Education should periodically determine the policy, mission and relevance of higher education in the light of new developments in the world of learning. Accordingly, the Ministry should determine the quantum of funds for higher education based on the mission, assessed costs and the opportunity costs to other subsectors of the education sector. The annual budget for higher education could be indexed to the gross domestic product or determined as a fixed percentage of the total budget of the education sector.

The National Council for Tertiary Education should develop new mechanism for allocating funds to tertiary education institutions which incorporates performance indicators based on policy imperatives developed for tertiary education institutions to promote accountability and efficiency. Public tertiary education institutions are required to fashion their own internal mechanism to apply funds allocated to them according to their own priorities. Public tertiary education institutions are also expected to provide accurate data to NCTE to facilitate performance monitoring and evaluation. In this regard, the managers of higher education institutions in Ghana should institute mechanisms to collect and validate data on their annual performance for transmission to NCTE. The afore-mentioned recommendations if implemented would facilitate the focusing on public funding on the policy imperatives of the tertiary education sector and facilitate the funding of higher education on the basis of available public funding and not on the basis of technological requirements for delivering educational services.

\section{References}

Adu, K. \& Opoku-Afriyie, K. J. (2002). Expenditure and Revenue Analysis of Tertiary Education Institutions in Ghana (1996-2000), National Council for Tertiary Education

Albrecht, D. \& Ziderman, A. (1992). Funding Mechanisms for Higher Education: Funding for Stability m Efficiency and Responsiveness, World Bank, 1-60

Binsbergen, P. (1996). Comparing Governance Structures of Higher Education Institutions - Towards a Conceptual Framework, in Geodgebuure, L. and Vugtht, F.V (eds) (1994). Comparative Policy Studies in Higher Education, 219-247

Bowen, H. R. (1980). The Cost of Higher Education: How Much Do Colleges and Universities Spend per Student and How Much They Should Spend, Carnegie Council on Policy Studies in Higher Education, Jossey-Bass, 18-20,

Brock, H. R. (1996). Budgeting Models and University Efficiency: A Ghanaian Case Study. Higher Education, 32, 113-127

Fincher, C. (1981). The Determinants of Educational Costs. Research in Higher Education, Agathon Press Inc, $15(2)$.

Girdwood, A. (1999). Tertiary Education Policy in Ghana: An Assessment: 1988-1999, World Bank, 1-60

Government of Ghana. (1990). White Paper on the Reforms to the Tertiary Education System, Government Proposals for the Restructuring and Reorganisation of Tertiary Education and Tertiary Institutions, Presented to the Ministry of Education by Command of the Provisional National Defence Council, Accra , Government of Ghana, 1-13

Government of Ghana. (1988). University Rationalisation Committee Report, Ministry of Education of Education and Culture, Ghana, pp. 269-326 
Halstead, D. K. (1974). State-wide Planning in Higher Education, Washington, DC: US, Government Printing Office

Layzell, D. T. (1999). Linking Performance to Funding Outcomes at the State Level for Public Institutions of Higher Education: Past, Present and Future. Research in Higher Education, 40(2), 233-246

Layzell, D. T. \& Mckeown, M. P. (1992). State Funding Formulas for Higher Education: Trends and Issues, Ashe Annual Meeting Paper

Mckeown, M. P. (1996). State Funding Formulas for Public Four -Year Institutions, State Higher Education Executive Officers, 3-33

MGT of America. (2001). Funding Formula, Use in Higher Education, Discussion Paper, 1-43

Miller, J. L., Jr. (1964). State Budgeting For Higher Education: The Use of Formulas and Cost Analysis, Ann Arbor: University of Michigan Institute of Public Administration

National Council for Tertiary Education. (2002). Expenditure and Revenue Analysis of Tertiary Education Institutions in Ghana, (1996-2000), National Council for Tertiary Education, 5-31

National Council for Tertiary Education. (1998). Evaluation of the Policy Objectives of the Reforms to the Tertiary Education System, National Council for Tertiary Education, 5-82

National Centre for Public Policy in Higher Education. (2003). Purposes, Policies, Performance Higher Education and the Fulfilment of a State's Public Agenda, National Centre for Public Policy and Higher Education, 1-30

Salmi, A. \& Hauptman, A. M. (2006). Innovations in Tertiary Education Financing: A Comparative Evaluation of Allocation Mechanisms, World Bank, 4-60

Sanyal, B. C. (1995). Innovations in University Management, UNESCO

Van der Laan, P. (2000). Aligning Incentives with Efficiency and Effectiveness Outcomes, Investing in Students Task Force, 1-49 